\title{
Comparison of bran, ispaghula, and lactulose on colon function in diverticular disease
}

\author{
M. A. EASTWOOD, A. N. SMITH, W. G. BRYDON, AND J. PRITCHARD \\ From the Wolfson Laboratories, Gastrointestinal Unit, Departments of Medicine and Clinical Surgery, \\ University of Edinburgh, and Department of Clinical Chemistry, Western General Hospital, Edinburgh
}

SUMMARY Bran, ispaghula (Fybogel), and lactulose were given to three groups of patients with diverticular disease for four weeks. Faecal weights, bile acids, fat and electrolytes, transit time, and colonic motility were estimated before and after treatment. Stool weight increased, notably with Fybogel. Cereal bran had the greatest effect on the transit time, reducing it significantly. There were no changes in faecal bile acids, fat or electrolytes. Coarse bran reduced colonic motility and the number of high pressure waves after food; Fybogel increased the basal pressure and was without effect on the food-stimulated pressures; whereas lactulose influenced neither. All agents paradoxically equally alleviated symptoms.

The symptoms of diverticular disease arise in patients who have, in the main, a small stool weight, prolonged intestinal transit time, and a raised intracolonic pressure (Painter, 1975). The rational basis of the treatment of diverticular disease is principally to influence the raised intraluminal pressure. As the various agents used in therapy would be expected to share in promoting this, we have examined three compounds which can be used in the treatment of diverticular disease: wheat bran, Fybogel, an ispaghula hydrophilic colloid (Godding, 1976), and lactulose, which is a synthesised disaccharide unabsorbed in the small intestine and hydrolysed by bacteria in the caecum.

\section{Methods}

Thirty-one patients in all were studied. The mean age was 60 years, range 32-84 years. They were recruited either from the outpatient clinic or from the radiology department. All gave informed consent to a trial of the agents used in their management. The diagnosis of diverticular disease was established by the demonstration of diverticula by a barium enema preceded by sigmoidoscopy and clinical examination. The symptoms ranged in all patients from constipation to diarrhoea or pain, while in others the disease was asymptomatic and a chance finding.

Received for publication 3 July 1978
Each patient was studied at home on his habitual diet. For one week stool was collected; at the start of the collection 40 barium impregnated markers were taken by mouth (Hinton et al., 1969). Such markers not only give a crude estimate of transit but act as indicators of the accuracy of stool collection. They also took polyethylene glycol: chromium sesquioxide (PEG: $\mathrm{Cr}_{2} \mathrm{O}_{3}$ ) capsules to mark the liquid and solid phases of the intestinal contents respectively (Findlay et al., 1974). The stool was collected from their homes and stored at $-20^{\circ} \mathrm{C}$, pooled, and freeze dried. Faecal wet weight, dry weight, bile acids (Evrard and Janssen, 1968), fat (Varley 1967), sodium, potassium, calcium and magnesium (flame photometry and atomic absorption spectrophotometry after charring with nitric acid), and PEG (Malawer and Powell, 1967), and $\mathrm{Cr}_{2} \mathrm{O}_{3}$ (Bolin et al., 1952) were individually estimated. Colonic motility was studied in fasting patients with open-ended tubes by means of which both basal measurement and the responses to food were measured in the distal colon and rectum. Measurements were taken at 15,20 , and $25 \mathrm{~cm}$ from the anal verge. The amplitude and frequency of the waves were calculated to give a motility index (Attisha and Smith, 1969). An analysis of the occurrence of waves of different amplitudes in the range $50-90 \mathrm{~cm}$ was performed.

Seven patients took the cereal bran-20 g/day; this was Prewitt's bran with a water-holding capacity of $5 \mathrm{~g} / \mathrm{g}$ dry weight. Each day's allowance of the bran preparation was provided packaged separately 
into individual plastic bags. Fourteen patients had the hydrophilic colloid agent Fybogel (ispaghula husk BPC), two sachets per day, and 10 patients were given the synthetic disaccharide laxative lactulose, $20-40 \mathrm{ml} /$ day. The patients were seen at weekly intervals during their course to check that they were suffering no deleterious effects and that they were taking their medication. Each treatment course lasted four weeks and the patients were retested during the last week. Because of the range of results these are expressed as a median and the Wilcoxon test for pair differences has been used for statistical analysis.

\section{Results}

All the agents administered were observed to increase the stool weight; only patients with Fybogel, however, reached significance $(\mathbf{P}<0.001)$ (Table). All patients expressed satisfaction at the increased stool production, but the patients on lactulose complained of excessive flatus. Cereal bran reduced the transit time from a median of 88 hours to $\mathbf{5 0}$ hours, which was significant $(\mathrm{P}<0.02)$. The overall recovery of pellets was $89.5 \%$ with a range of 28 to 40 capsules returned. There was no effect of either bran, Fybogel, or lactulose on faecal bile acid fat, sodium, potassium, calcium, magnesium excretion, or on the PEG: $\mathrm{Cr}_{2} \mathrm{O}_{3}$ ratio. The effect of bran and lactulose on the basal motility was insignificant (Fig. 1). However, Fybogel increased the basal motility from a median of 1150 (range 284-2034) to 2100 (range 0-3309), which was

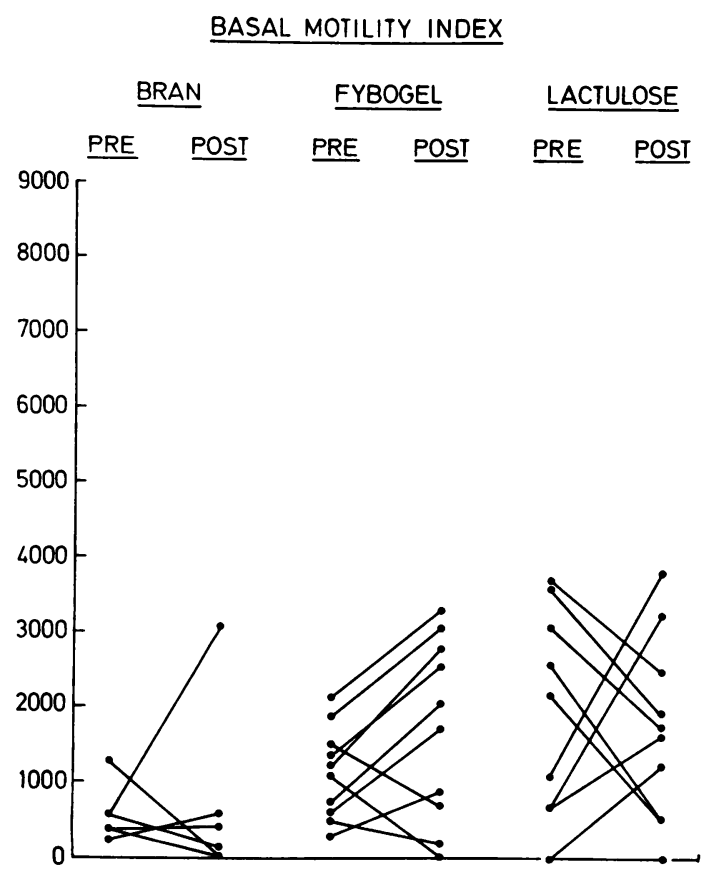

Fig. 1 Effect of bran, Fybogel, and lactulose on basal motility index, before and after treatment.

significant by Wilcoxon test for pair difference $(P<0.001)$. Bran generally reduced the foodstimulated pressure (Fig. 2) but there was no significant effect of Fybogel or lactulose on the food-stimulated colonic motility.

Table Effect on colonic function of treatment-median (range)

\begin{tabular}{|c|c|c|c|c|c|c|}
\hline & \multicolumn{2}{|l|}{ Bran } & \multicolumn{2}{|l|}{ Fybogel } & \multicolumn{2}{|l|}{ Lactulose } \\
\hline & Before & During & Before & During & Before & During \\
\hline $\begin{array}{l}\text { Stool weight } \\
(\mathrm{g} / 24 \mathrm{~h})\end{array}$ & $\begin{array}{l}82 \\
(50-150)\end{array}$ & $\begin{array}{l}103 \\
(50-188)\end{array}$ & $\begin{array}{l}75 \\
(52-169)\end{array}$ & $\begin{array}{l}108 \\
(67-208)\end{array}$ & $\begin{array}{l}95 \\
(25-199)\end{array}$ & $\begin{array}{l}160 \\
(27-190)\end{array}$ \\
\hline Transit time (h) & $\begin{array}{l}88 \\
(53-168)\end{array}$ & $\begin{array}{l}50 \\
(24-84)\end{array}$ & $\begin{array}{l}62 \\
(29-120)\end{array}$ & $\begin{array}{l}72 \\
(9-120)\end{array}$ & $\begin{array}{l}48 \\
(48-120)\end{array}$ & $\begin{array}{l}48 \\
(24-108)\end{array}$ \\
\hline PEG/Cr ratio & - & - & $\begin{array}{l}1 \cdot 10 \\
(0 \cdot 79-1 \cdot 71)\end{array}$ & $\begin{array}{l}0.96 \\
(0.59-1 \cdot 25)\end{array}$ & $\begin{array}{l}(+77 \\
0 \cdot 77 \\
(0 \cdot 27-1 \cdot 22)\end{array}$ & $\begin{array}{l}0.87 \\
(0.31-1 \cdot 18)\end{array}$ \\
\hline Motility_basal & $\begin{array}{l}481 \\
(369-1343)\end{array}$ & $\begin{array}{l}201 \\
(35-3064)\end{array}$ & $\begin{array}{l}1150 \\
(284-2034)\end{array}$ & $\begin{array}{l}2110 \\
(0-3309)\end{array}$ & $\begin{array}{l}945 \\
(0-3845)\end{array}$ & $\begin{array}{l}1257 \\
(0-3853)\end{array}$ \\
\hline $\begin{array}{l}\text { Motility-after } \\
\text { food }\end{array}$ & $\begin{array}{l}878 \\
(575-1685)\end{array}$ & $\begin{array}{l}539 \\
(0-2605)\end{array}$ & $\begin{array}{l}2096 \\
(1508-3051)\end{array}$ & $\begin{array}{l}2780 \\
(864-4111)\end{array}$ & $\begin{array}{l}2441 \\
(1378-6766)\end{array}$ & $\begin{array}{l}2972 \\
(1355-5693)\end{array}$ \\
\hline $\begin{array}{l}\text { Faecal bile acids } \\
(\mathrm{mmol} / 24 \mathrm{~h})\end{array}$ & $\begin{array}{l}0.670 \\
(0 \cdot 438-1 \cdot 37)\end{array}$ & $\begin{array}{l}0.41 \\
(0 \cdot 238-1 \cdot 82)\end{array}$ & $\begin{array}{l}0.363 \\
(0 \cdot 283-1 \cdot 47)\end{array}$ & $\begin{array}{l}0.564 \\
(0 \cdot 210-1 \cdot 154)\end{array}$ & $\begin{array}{l}0.516 \\
(0 \cdot 145-0.990)\end{array}$ & $\begin{array}{l}0.545 \\
(1 \cdot 125-0.810)\end{array}$ \\
\hline $\begin{array}{l}\text { Fat } \\
(\mathrm{mmol} / 24 \mathrm{~h})\end{array}$ & - & - & $\begin{array}{l}10 \cdot 0 \\
(5-22 \cdot 8)\end{array}$ & $\begin{array}{l}10 \cdot 0 \\
(6 \cdot 9-24 \cdot 9)\end{array}$ & $\begin{array}{l}12 \cdot 0 \\
(4 \cdot 1-19 \cdot 7)\end{array}$ & $\begin{array}{l}11 \cdot 6 \\
(1 \cdot 8-17 \cdot 1)\end{array}$ \\
\hline $\begin{array}{l}\text { Sodium } \\
(\mathrm{mmol} / 24 \mathrm{~h})\end{array}$ & - & - & $\begin{array}{l}0 \cdot 48 \\
(0 \cdot 16-7 \cdot 76)\end{array}$ & $\begin{array}{l}1 \cdot 21 \\
(0 \cdot 33-7 \cdot 33)\end{array}$ & $\begin{array}{l}1 \cdot 50 \\
(0 \cdot 14-7 \cdot 64)\end{array}$ & $\begin{array}{l}2 \cdot 40 \\
(0 \cdot 16-11 \cdot 43)\end{array}$ \\
\hline Potassium & - & - & $\begin{array}{l}6 \cdot 12 \\
(4 \cdot 95-13 \cdot 23)\end{array}$ & $\begin{array}{l}9 \cdot 73 \\
(6 \cdot 88-17 \cdot 95)\end{array}$ & $\begin{array}{l}11 \cdot 7 \\
(2 \cdot 78-19 \cdot 3)\end{array}$ & $\begin{array}{l}13 \cdot 5 \\
(1 \cdot 42-16 \cdot 9)\end{array}$ \\
\hline $\begin{array}{l}\text { Calcium } \\
\text { (mmol/24 h) }\end{array}$ & & & $\begin{array}{l}12 \cdot 9 \\
(5 \cdot 62-19 \cdot 1)\end{array}$ & $\begin{array}{l}12 \cdot 1 \\
(10 \cdot 1-21 \cdot 4)\end{array}$ & $\begin{array}{l}136 \\
(5 \cdot 2-24 \cdot 1)\end{array}$ & $\begin{array}{l}13 \cdot 50 \\
(2 \cdot 90-33 \cdot 3)\end{array}$ \\
\hline $\begin{array}{l}\text { Magnesium } \\
(\mathrm{mmol} / 24 \mathrm{~h})\end{array}$ & & & $\begin{array}{l}3 \cdot 5 \\
(1 \cdot 75-6 \cdot 64)\end{array}$ & $\begin{array}{l}4 \cdot 5 \\
(2 \cdot 17-8 \cdot 32)\end{array}$ & $\begin{array}{l}4.44 \\
(160-8 \cdot 65)\end{array}$ & $\begin{array}{l}3 \cdot 87 \\
(0 \cdot 70-5 \cdot 74)\end{array}$ \\
\hline
\end{tabular}




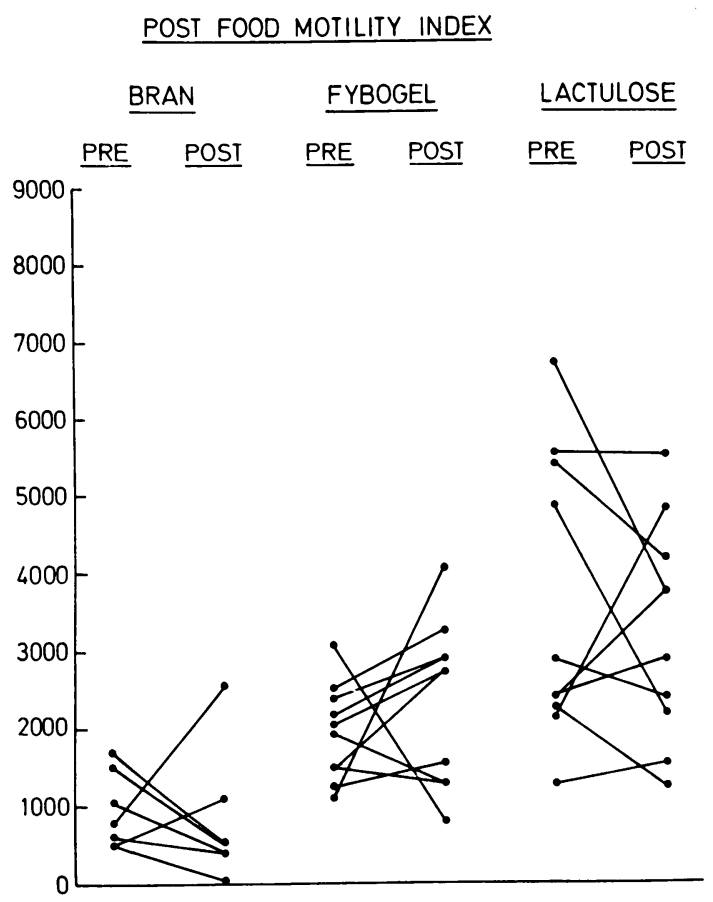

Fig. 2 Effect of bran, Fybogel, and lactulose on post-food motility index before and after treatment.

Changes in motility expressed as a 'motility index' may mask the nature of the underlying motor response, as this is a product of the wave amplitude and the duration of the motor effect. A common motility result could be arrived at by many smaller waves or less frequent large waves. Waves of greater amplitude might, however, be more damaging to the colon and responsible for some of the symptoms or of the pathology of diverticular disease. Furthermore, it could be argued that these are the ones which the effective agents should be abolishing. Counts of the waves (Fig. 3) in the amplitude range $50-90 \mathrm{~cm} \mathrm{H}_{2} \mathrm{O}$ were made and the average number recorded per patient in each treatment group. On bran, the number of waves was reduced at each $10 \mathrm{~cm}$ level in a one hour period of activity after a food stimulus. Fybogel, on the contrary, raised the average number of waves, whereas lactulose had no effect. Since the effect of Fybogel in raising the basal motility and the number of high pressure waves present after food is contrary to what one expects of a bulk-acting agent, the experiment was repeated with four patients on four sachets of Fybogel per day. The stool weight was increased two to four times. The basal motility again increased but there was no constant change in the faecal sodium, potassium, calcium, and magnesium.

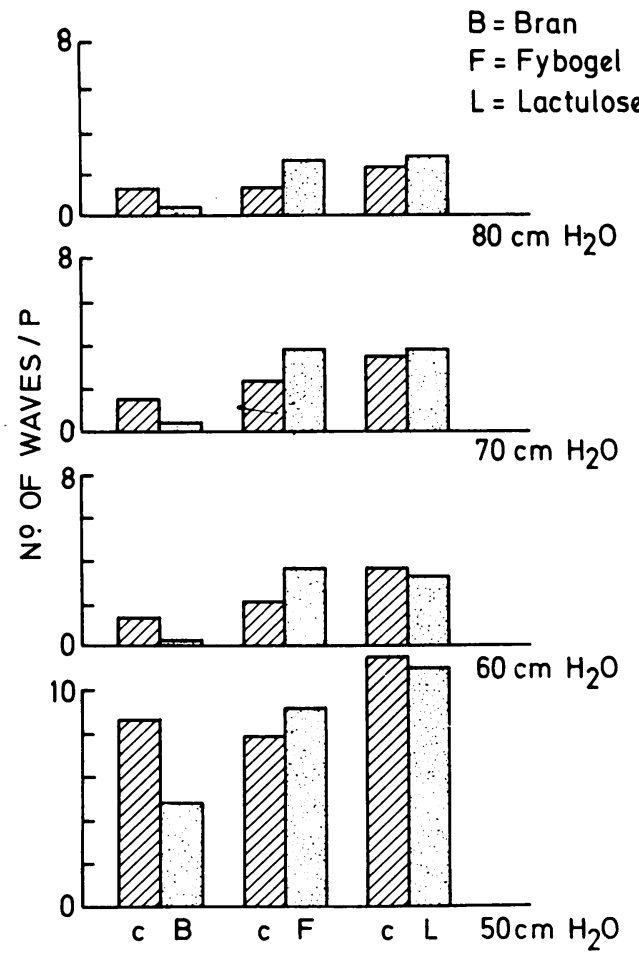

Fig. 3 Effect of bran $(B)$, Fybogel $(F)$, and lactulose $(L)$ on post-cibal waves before $(c)$ and after treatment $(B, F$, and $L)$.

\section{Discussion}

It is now established that important bulk agents such as bran (Findlay et al., 1974), sterculia (Srivastava et al., 1976), and methylcellulose (Hodgson, 1972) used in the treatment of large bowel disease may be expected to lower the intraluminal pressure within the colon. The reasons for this may be that the additional contents oppose the activity of the smooth muscle or increase the intraluminal width. A change of viscosity may be a contributory factor. Bulk-forming cereal fibre should lower pressure by one or other of these means; however, the problem is to determine which fibre should be taken, as not all forms of bran consistently lower the lumen pressure. The usual fibre suggested is cereal fibre in the form of miller's bran, but it is not clear what form of bran is advisable, nor is it known if other forms derived from fruit and vegetable sources are equally of value. A rough form, Prewitt's, was found to be more effective at the same dose than a fine form (Allinson's), which had a reduced water-binding capacity and thus a lowering bulk-forming capacity (Kirwan et al., 1974). There are several approaches to the selection of fibre. On the one hand, one can 
select a source of fibre by its chemical constituents, such as its content of cellulose, pectin, hemicellulose, and lignin (Cummings et al., 1978). This information is not readily available. Alternatively, a physicochemical approach can be applied using the waterholding capacity of the fibre, which is proportional to its bulk-acting or promoting properties and, to a lesser extent, the cation exchange capacity (Kirwan et al., 1974). Such measurements, however, are provisional in their value in predicting their effect on bowel function, in that the fibre may be metabolised by faecal flora. This leads to the production of hydrolytic end products which may themselves be absorbed from the caecum or may have biological effects of their own (Eastwood, 1975).

The therapeutic agents which we tested might have been expected in general to decrease intracolonic pressure. The pretreatment pressures in the three groups differ in their range, though all the measurements were obtained using the same apparatus, the same technique, and the same technician; this type of result reflects the diversity which can be obtained in the manometry of diverticular disease (Eastwood et al., 1978). However, given raised pretreatment pressures, a reduction would be expected after successful therapy and not, as is found for Fybogel, an increase. Coarse bran has already been shown to exert a reduction in pressure (Kirwan et al., 1974). There is therefore no uniform relationship between the modification of symptoms and the efficacy of the compounds in lowering pressure, in the short term at least. This raises some doubt about the overall importance of 'features' of diverticular disease-that is, low stool weight, the prolonged transit time, and the raised intraluminal pressure-which were formerly thought to be hallmarks of this disease. Although two of the agents used here raised the intraluminal pressure or left it unchanged, both produced an equivalent symptomatic relief. The patients were mainly complaining of constipation, apart from abdominal pain and discomfort, and it is possible that part of the therapeutic effect is achieved by overcoming another factor such as stasis. Yet agents which raise or leave pressure unchanged may not in the long run be entirely free of the risk of producing further damage to the bowel in diverticular disease. Thus, we would have to conclude that bran remains the most efficacious agent by adding to the stool weight and lowering the intraluminal pressure in diverticular disease.
We gratefully acknowledge that this work was done during the tenure of grant SHERT 491 (to A.N.S.) and with assistance from Reckitts and Colman, Duphar Laboratories, and the Incorporated National Association of British and Irish Millers. Miss Elizabeth Drummond gave invaluable help with the recording of the motility data.

\section{References}

Attisha, R. P., and Smith, A. N. (1969). Pressure activity of the colon and rectum in diverticular disease before and after sigmoid myotomy. British Journal of Surgery, 56, 891-894.

Bolin, D. W., King, R. P., and Klosterman, E. W. (1952). A simplified method for the determination of chromic oxide $\left(\mathrm{Cr}_{2} \mathrm{O}_{3}\right)$ when used as an index substance. Science, 116, 634-635.

Cummings, J. H., Southgate, D. A. T., Branch, W., Houston, H., Jenkins, D. J. A., and James, W. P. T. (1978). Colonic response to dietary fibre from carrot, cabbage, apple, bran and guagum. Lancet, 1, 5-9.

Eastwood, M. A. (1975). Medical and dietary management. Clinics in Gastroenterology, 4, 85-97.

Eastwood, M. A., Smith, A. N., Brydon, W. G., and Pritchard, J. (1978). Colonic function in patients with diverticular disease. Lancet, 1, 1181-1182.

Evrard, E., and Janssen, G. (1968). Gas liquid chromatographic determination of human fecal bile acids. Journal of Lipid Research, 9, 226-236.

Findlay, J. M., Mitchell, W. D., Eastwood, M. A., Anderson, A. J. B., and Smith A. N. (1974). Intestinal streaming patterns in cholerrhoeic enteropathy and diverticular disease. Gut, 15, 207-212.

Findlay, J. M., Smith, A. N., Mitchell, W. D., Anderson, A. J. B., and Eastwood, M. A. (1974). Effects of unprocessed bran on colon function in normal subjects and in diverticular disease. Lancet, 1, 146-149.

Godding, E. W. (1976). Constipation and allied disorders, reprinted from the Pharmaceutical Journal. Pharmaceutical Press: London.

Hinton, J. M., Lennard-Jones, J. E., and Young, A. C. (1969). A new method for measuring gut transit time using radio-opaque markers. Gut, 10, 842-847.

Hodgson, J. (1972). Effect of methyl cellulose on rectal and colonic pressures in treatment of diverticular disease. British Medical Journal, 3, 729-731.

Kirwan, W. O., Smith, A. N., McConnell, A. A., Mitchell, W. D., and Eastwood, M. A. (1974). Action of different bran preparations on colonic function. British Medical Journal, 4, 187-189.

Malawer, S. J., and Powell, D. W. (1967). An important turbidimetric analysis for polyethylene glycol utilising an emulsifer. Gastroenterology, 53, 250-256.

Painter, N. S. (1975). Diverticular Disease of the Colon, Heinemann: London.

Srivastava, G. S., Smith, A. N., and Painter, N. S. (1976). Sterculia bulk-forming agent with smooth-muscle relaxant versus bran in diverticular disease. British Medical Journal, 1, 315-318.

Varley, H. (1967). Practical Clinical Biochemistry. pp. 419-420. Heinemann: London. 